Journal of Curriculum and Instruction (JoCl), November 2009, Volume 3, Number 2, (James O.

McDowelle)

\title{
A Contemporary Consideration of Transformative Leadership
}

\author{
James O. McDowelle \\ East Carolina University
}

\begin{abstract}
Although the term transformational leadership was introduced by Downton (1973), the concept did not gain credibility and wide acceptance until the publication of the book Leadership by James Macgregor Burns (1978). Burns, a University of Maryland professor, said that "transformational leadership occurs when one or more persons engage with others in such a way that leaders and followers raise one another to higher levels of morality" (p. 20). Burns contrasted transformational leadership with transactional leadership, defining transactional leadership as encompassing those transactions that occur when leaders give rewards in exchange for specific behavior by followers. Followers working strictly for a paycheck exemplify transactional leadership. In contrast, transformational leadership involves the transformation of the attitudes, motivations, and behaviors of both leaders and followers (Jackson \& Parry, 2008).
\end{abstract}

Mohandas Ghandi is frequently cited as a classic exemplar of transformational leadership (Northouse, 2007). Ghandi spent lengthy periods in prison and withstood health-threatening fasts to create a transformative moral vision based on what he called truth (Fisher, 1983; Nahavandi, 2003). His willingness to actually live his spiritual vision created ethical, emotional, and intellectual bonds with his followers. This example lays the groundwork for conversations about and investigations in transformative leadership in today's school settings. It should be noted that the terms transformational leadership and transformative leadership are sometimes used interchangeably in current literature.

\section{Viewing Transformative Leadership through a Contemporary Prism}

The concept of transformational leadership has dominated the leadership literature since the early 1980's (Jackson \& Parry, 2008; Northouse, 2007). Bass and Avolio (1993) expanded the concept of transformational leadership to include more affective aspects that related to the feelings and emotions of both followers and leaders. They also delineated key elements of the concept: (a) idealized influence, (b) inspirational motivation, (c) intellectual stimulation, and (d) individualized consideration. These four elements are still cited by contemporary leadership theorists and researchers as fundamental components of transformational leadership (Kim, 2006; Leithwood \& Duke, 1999; Northouse, 2007). Lowe and Gardner (2001) conducted a content analysis of the issues of The Leadership Quarterly published from 1990 to 2000. They found that one third of the research published in the Quarterly was associated with transformational leadership. 
The concept of transformative leadership continues to evolve and remains a vital and important part of the current leadership literature. In this issue of the Journal of Curriculum and Instruction ( $\mathrm{JOCl}$ ) we will consider the concept of transformative leadership through the prism of contemporary concepts, some of which were introduced after the term transformational leadership gained currency. For example, emotional intelligence and spiritual intelligence are recent additions to the leadership lexicon; these terms did not exist when Burns developed his notion of transformational leadership. Although the concept of critical theory predates transformational leadership, the application of critical theory to transformational leadership generates fresh perspectives and insights into the study of school leadership. All three concepts have major implications for school leaders in the exercise of transformative leadership. This issue of $\mathrm{JoCl}$ considers both research and theory in the application of these emerging concepts of transformative leadership.

\section{Critical Theory}

In his invited piece, David Callejo Pérez (2009) provides a critical examination of notions of leadership and the role curriculum leadership can have in substantial change in our schools. The author analyzes school accountability in the context of critical theory and then offers a rich analysis of transformative leadership using critical theory to specifically challenge traditional assumptions about power, empathy, and ethics in schools. Callejo suggests a model for developing an inward leadership approach to transformative change and then describes several approaches for sustaining change in schools with a focus on reintegrating evaluation with curriculum and school leadership. Callejo shares a comprehensive survey of the current state of school leadership and innovative recommendations for initiating and sustaining change in schools. The argument put forth in this article serves as a bold challenge to the current generation of school leaders to confront the complex and multilayered issues of transformative leadership and "...contribute positively to the challenges confronting schools today" (Callejo Pérez, 2009, p. 18).

\section{Emotional Intelligence}

Lane Mills (2009) describes a meta-analysis that attempts to ascertain if emotional intelligence can be linked to effective leadership. Since Bass and Avolio (1985) expanded the concept of transformational leadership to place an emphasis on the emotions and feelings of followers, the linkage between emotional intelligence and transformational leadership has been apparent. Three of the key components of transformational leadership cited by Bass and Avolio, (a) idealized influence, (b) inspirational motivation, and (c) individualized consideration, are part of the vocabulary of emotional intelligence. Consequently, the finding that there is a moderately strong relationship between emotional intelligence and effective leadership has major implications for the practice of transformative leadership. One criticism of the research on transformative leadership is that the term lacks conceptual clarity (Northouse, 2007). The work by Mills focuses on specific components of transformative leadership 
Journal of Curriculum and Instruction (JoCl), November 2009, Volume 3, Number 2, (James O.

McDowelle)

associated with affective or emotional factors, key components of transformative leadership. The positive correlation established in this meta-analysis enhances, to a certain degree, the conceptual clarity of the broader concept of transformational leadership.

\section{Spiritual Intelligence}

The perspective article by Barbara Howard, Precious Guramatunhu-Mudiwa, and Stephen White (2009), explores the concept of spiritual intelligence as a critical factor in transformative leadership. Since the inception of the concept of transformative leadership, morality and ethics have played key roles. As stated earlier, Burns (1978) contended that a crucial role of transformative leadership was to raise both leaders and followers to a higher level of morality. Bass (1985) echoed this contention that the foundation of transformative leadership was moral authority. The authors of this article purposefully place spiritual intelligence as a component of transformative leadership in the context of the North Carolina Educational Leadership Standards (North Carolina State Board of Education, 2006). This contextual alignment provides a response to persistent criticism that transformative leadership lacks a contextual or situational basis (Jackson \& Parry, 2008, p. 12).

\section{A Professional Development Transformative Leadership Model}

Janice Leilani View, Elizabeth K. Demulder, Mary Kaylor, and Staci M. Stribling (2009) describe a model for professional development that employs many of the elements explored in depth in this issue including transformative leadership, critical theory, and emotional intelligence. These components come together within a model for professional development that places a major focus on transformative leadership as a way to cultivate both teaching expertise and leadership capacity in the form of P-12 teacher leaders. This model is congruent with the traditional conception of transformational leadership in its emphasis on leadership roles being assumed by many members within an organization and is consistent with the emerging concept of distributive school leadership. Exponents of distributive leadership contend that school leadership has become so complex and onerous that it must now be distributed among many members of the school and cannot be limited to one or two school leaders. In addition, leadership should be based on expertise and a willingness to serve, not merely the position of the leader. The professional development model presented in this article can serve as a vehicle to prepare teacher leaders for distributive leadership.

\section{Closing Thoughts}

Jackson and Parry (2008) admit, "We keep waiting for the transformational leadership 'bubble' to burst and for it to be relegated to the historical scrap bin as another management fad" (p. 33); however, they note that in reality the bubble never bursts and transformational leadership somehow retains its intellectual vitality. It is true that leadership fads come and go almost as fast as trendy diets, but the basic principles 
Journal of Curriculum and Instruction (JoCl), November 2009, Volume 3, Number 2, (James O.

McDowelle)

of transformative leadership_ deep, transforming engagement with all stakeholders and serious moral and ethical transformation - will continue to be important leadership concerns and will cause transformative leadership to endure as a touchstone for those involved in the exercise of school leadership. We hope this edition of the Journal of Curriculum and Instruction will shed some light on the debates and discussions of this fascinating subject.

\section{References}

Bass, B. M. (1985). Leadership and performance beyond expectation. New York: Free Press.

Bass, B. M., \& Avolio, B. J. (1993).Transformational leadership: A response to critiques. In M. Chemers \& R. Ayman (Eds.), Leadership theory and research: Perspectives and directions (pp. 49-80). San Diego, CA: Academic Press.

Burns, J. M. (1978). Leadership. New York: Harper and Row.

Callejo Pérez, D. M. (2009). Curriculum and transformation: Rethinking leadership and schools all over again. Journal of Curriculum and Instruction 3(2), 6-21. doi:10.3776/joci.2009.v3n2p6-21.

Downton, J. V., Jr. (1973). Rebel leadership. New York: Free Press.

Fisher, L. (1983). The life of Mahatma Ghandhi. New York: Harper Publishing.

Howard, B. B., Guramatunhu-Mudiwa, P., \& White, S. R. (2009). Spiritual intelligence and transformational leadership: A new theoretical framework. Journal of Curriculum and Instruction, 3(2), 54-67. doi:10.3776/joci.2009.v3n2p54-67.

Jackson, B., \& Parry, K. (2008). A very short, fairly, interesting and reasonably cheap book about leadership. Thousand Oaks, CA: Sage Publications.

Kim, E. (2006). Transformational leadership. In F. W. English (Ed.), Encyclopedia of educational leadership and Administration (pp. 1031-1032). Thousand Oaks, CA: Sage Publications.

Leithwood, K., \& Duke, D. (1999). A century's quest to understand school leadership. In J. Murphy \& K. S. Louis (Eds.), Handbook of research on educational administration (pp. 45-72). San Francisco: Jossey-Bass.

Lowe, K. B., \& Gardner, W. L. (2001). Ten years of The Leadership Quarterly: Contributions and challenges for the future. The Leadership Quarterly, 11(4), 648-657. 
Journal of Curriculum and Instruction (JoCl), November 2009, Volume 3, Number 2, (James O.

McDowelle)

Mills, L. B. (2009). A meta-analysis of the relationship between emotional intelligence and effective leadership. Journal of Curriculum and Instruction, 3(2), 22-38. doi:10.3776/joci.2009.v3n2p22-38.

Nahavandi, A. (2003). The art and science of leadership. Upper Saddle River, NJ: Prentice Hall.

Northouse, P. G. (2007). Leadership: Theory and practice. Thousand Oaks, CA: Sage Publication.

North Carolina State Board of Education. (2006). The standards for school executives [PDF document]. Retreived from http://www.ncpublicschools.org/docs/profdev/ guidelines/school-executives-standards/principals.pdf

View, J. L., DeMulder, E. K., Kayler, M., \& Stribling, S. M. (2009). Cultivating transformative leadership in P-12 schools and classrooms through critical teacher professional development. Journal of Curriculum and Instruction, 3(2), 39-53. doi:10.3776/joci.2009.v3n2p39-53.

\section{About the Guest Editor:}

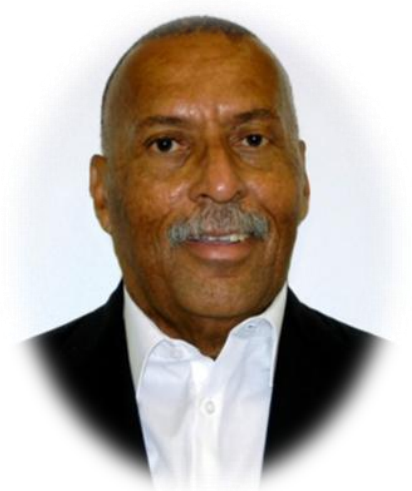

James O. McDowelle received his doctorate in education from the University of Virginia. He has served as a teacher, principal, and superintendent in the public schools. Prior to beginning a career in education he served as a captain in Vietnam and received the Bronze Star. This experience sparked a lifelong interest in leadership. McDowelle is the author of several books about educational leadership, including Leading with Emotion. He is presently completing a book on the interpersonal skills of the principalship for Pearson Education. McDowelle is a professor in the Department of Educational Leadership at East Carolina University. Contact email is mcdowellej@ecu.edu. 